\section{Fire vs. Herbicide?}

\section{The economics of her- bicides and prescribed fire are compared in managing mesquite.}

\author{
By Richard Teague ${ }^{1}$, Jim \\ Ansley, Urs Kreuter, Jim \\ McGrann, and Bill Pinchak
}

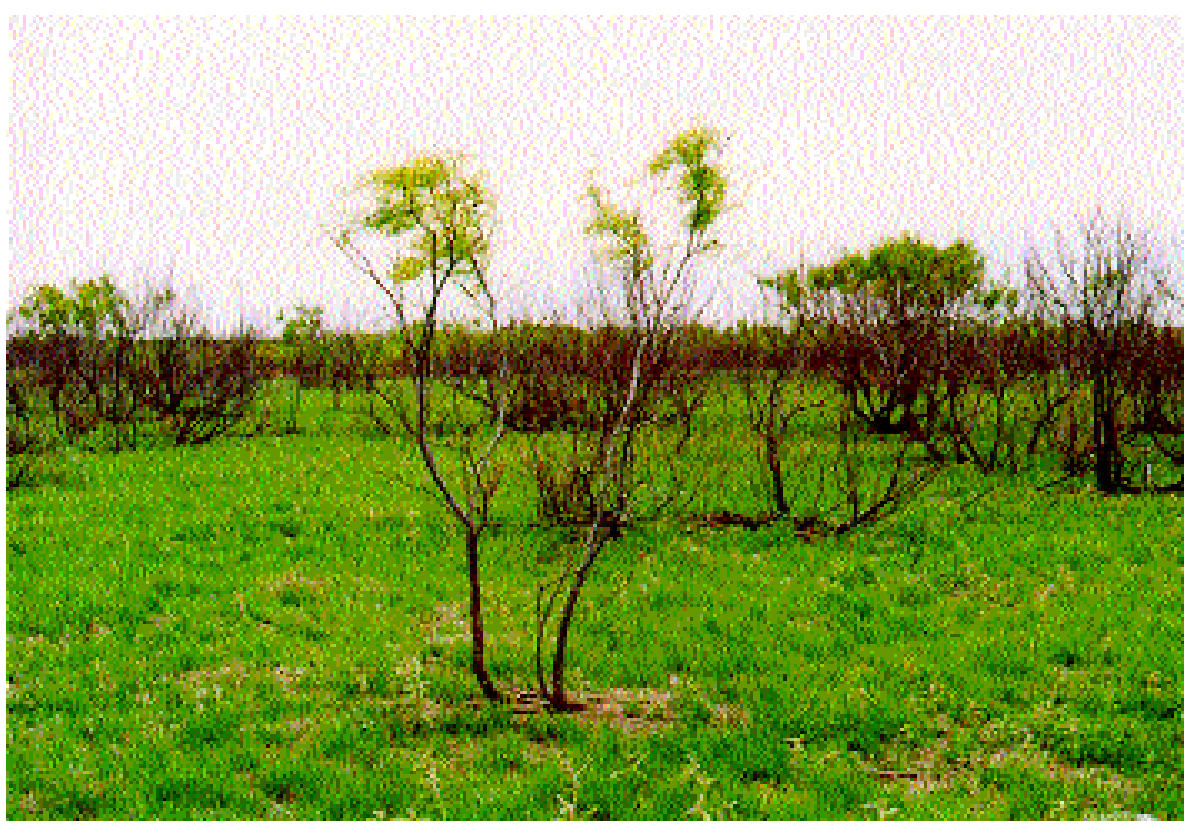

Plate 1. Mesquite in early summer after application of prescribed winter burn.

mated by determining the differences in net present value and benefit-cost ratio of treated vs. untreated land over a 30-year period for a hypothetical 20,000-acre ranch.

A project was considered economically feasible if discounted returns exceed discounted costs (i.e. net present value $\geq 0$ ). Treatments with higher net present values were considered economically superior. The benefit-cost ratio was calculated by dividing the present value of returns (benefits) by the present value of treatment costs and maintenance. The benefit-cost ratio must be greater than 1.0 for the treatment to be economically feasible. The changes in land value were not taken into account because land values are often unrelated to productivity and are frequently driven by speculative investors.

The analyses were based on the assumptions that income and operating costs are incurred at the end of each year, while initial treatment costs occur at the beginning of year 1 . Treatment costs were based on data from the Waggoner Experimental Ranch in north Texas. The projected income over costs is also calculated for each 30-year scenario. Since net present value and benefit-cost ratio es timates are correlated, we discuss only the net present value of each treatment analyzed. However, benefit-cost ratios are also presented to accommodate preferences for either measure.

Analysis showed no sensitivity to a range of discount rates so a rate of $5 \%$ is used. We used the current rate for leased cow-calf ranchland in the Rolling Plains of Texas of $\$ 90$ /Animal Unit/year. The parameter val-

Explanation Of Economic Terms

Benefit-Cost ratio - The return for each dollar invested. A benefit-cost ratio of 2 means for every $\$ 1$ invested a return of $\$ 2$ is realized.

Discount rate - The rate at which a dollar is decreasing in value with time.

Present value of costs-Value of costs adjusted to account for the decreasing value of a dollar into the future.

Present value of returns - Value of returns adjusted to account for the decreasing value of a dollar into the future.

Net present value - A dollar now will be worth less in the future due to inflation and other factors. For instance, at a discount rate of $5 \%$, for every $\$ 1$ now, you would need $\$ 4.32$ in 30 year's time. Net present value is a means of comparing a present dollar with the same dollar value in the future.
The economic efficiency of treating brush with fire or herbicide was esti- 
Table 1. Baseline parameter values used in the analysis.

\begin{tabular}{llcc}
\hline \hline \multicolumn{1}{c}{ Parameter } & Herbicide & Fire \\
\hline 1 & $\%$ Area to be treated & 50 & 50 \\
2 & Brush situation on treated area (\% mesquite aerial cover) & 30 & 30 \\
3 & Discount rate $\%)$ & 5 & 5 \\
4 & Income tax rate $(\%)$ & 15 & 15 \\
5 & Capital gains tax rate $(\%)$ & 20 & 20 \\
6 & Wildlife income (\$/ac) & 3 & 3 \\
7 & Treatment longevity (years) & 20 & 7 \\
8 & Cost (\$/ac) Initial treatment $\quad$ Follow-up burn treatments & 23 & 2.5 \\
& 2.5 & 2.5 \\
9 & Carrying capacity untreated area (ac/Animal Unit/year)* & 39 \\
10 Carrying capacity treated area before treatment (30\% mesquite) $* *$ & 39 & 30 \\
11 Carrying capacity treated area after treatment (10\% mesquite)** & 30 & 14 \\
\hline
\end{tabular}

*Land that has shallow-clay soil of relatively low productivity for herbage and very low amounts of brush. Carrying capacity has been calculated by allocating $25 \%$ of peak forage standing crop @ $26 \mathrm{lb} /$ Animal Unit/day using 5 years of data from Teague et al. (1999).

** Land that has moderately productive clay-loam soils where the major presence of mesquite occurs. Carrying capacity has been calculated as above.

ues used for the majority of scenarios are presented in Table 1.

The current recommendation for herbicide application to control mesquite on large ranches is to aerially spray $0.25+0.25 \mathrm{lb} / \mathrm{ac}$ clopyralid + triclopyr herbicide at a cost of $\$ 23 / \mathrm{ac}$. Costs of burning in north Texas, including the cost of dozing firebreaks and pre-burning blacklines range from $\$ 2.50 / \mathrm{ac}$ to $\$ 2.80 / \mathrm{ac}$.

\section{Mesquite and forage production}

Recent work in north Texas has defined the long-term regrowth and invasion of mesquite after a root-killing herbicide has been applied. The resulting reduction in forage production, and hence carrying capacity, as mesquite aerial cover increased over a 30-year period, is summarized in Fig. 1.

The assumed changes in productivity (carrying capacity) over time after prescribed burning versus not treating the brush are presented in Fig. 2 and are based on results for north Texas in which top-killing treatment effects lasted 6 to 7 years. We recognize that fire is not as effective in reducing brush cover as herbicide treatment, and consider two scenarios in which response to brush reduction is $50 \%$ or $75 \%$ that of herbicide treatment.

Using data in which root-killing treatment effects lasted up to 20 years, we considered 20 - and 30-year longevity scenarios after herbicide application with no follow-up treatment (Fig. 3). In addition, two other scenar- ios were considered with the 20-year treatment life after herbicide application (Fig. 4). These were follow-up treatment of prescribed fire 16 years or 20 years after the initial herbicide application.

\section{Management changes to enhance the effectiveness of burning}

Pre- and post-burn rests from grazing are necessary to provide adequate amounts and continuity of grass fuel for effective burns, and to allow forage to recover sufficiently before grazing again. To produce an adequate top-

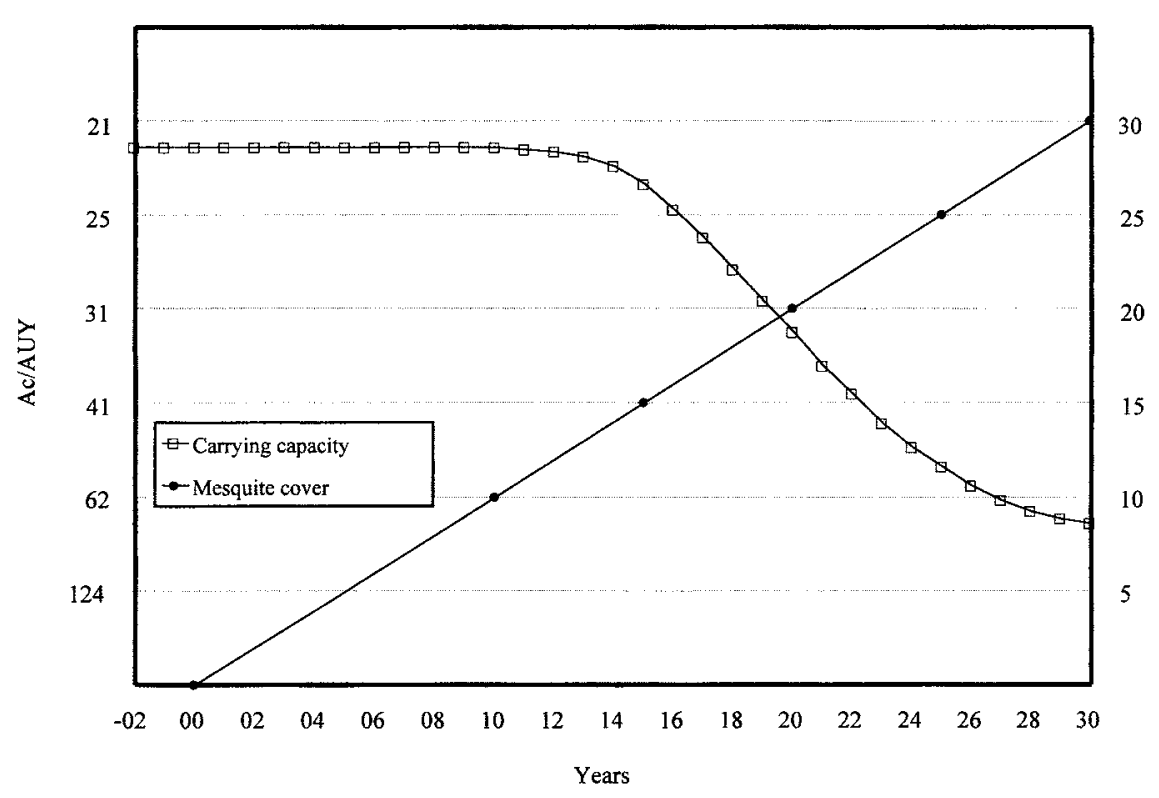

Fig. 1. Carrying capacity decline over time, due to increasing mesquite brush on the Waggoner Experimental Ranch. killing fire for managing mesquite, herbaceous fine fuel must exceed 1500 lb/acre.

Moderately stocked, one-herd, multiple-pasture systems facilitate such resting. These systems allow the use of fire in non-drought years at about 7 year intervals to avoid having to hire extra land to ensure adequate pre- and postburn rest of the treated land. By consolidating herds, most ranchers would be able to implement at least a 4-pasture, 1-herd system of management without incurring extra fencing costs.

However, scenarios that do require extra fencing to implement resting are considered in this analysis. The economic consequences of adding electric fencing or conventional 5-wire fencing in year 1 are considered, using costs of $\$ 350$ and $\$ 3,500$ per mile of fence, respectively. If continuous grazing were used, alternative grazing would have to be hired to allow the continuously grazed areas to rest before and after burning. We also recognize that if fire is followed by drought, herbaceous response is delayed. Therefore, we delay the increase in herbage by 1 year.

\section{Wildlife and brush clearing}

Mesquite brush provides cover and has some feed value for wildlife. Generally for wildlife purposes, 


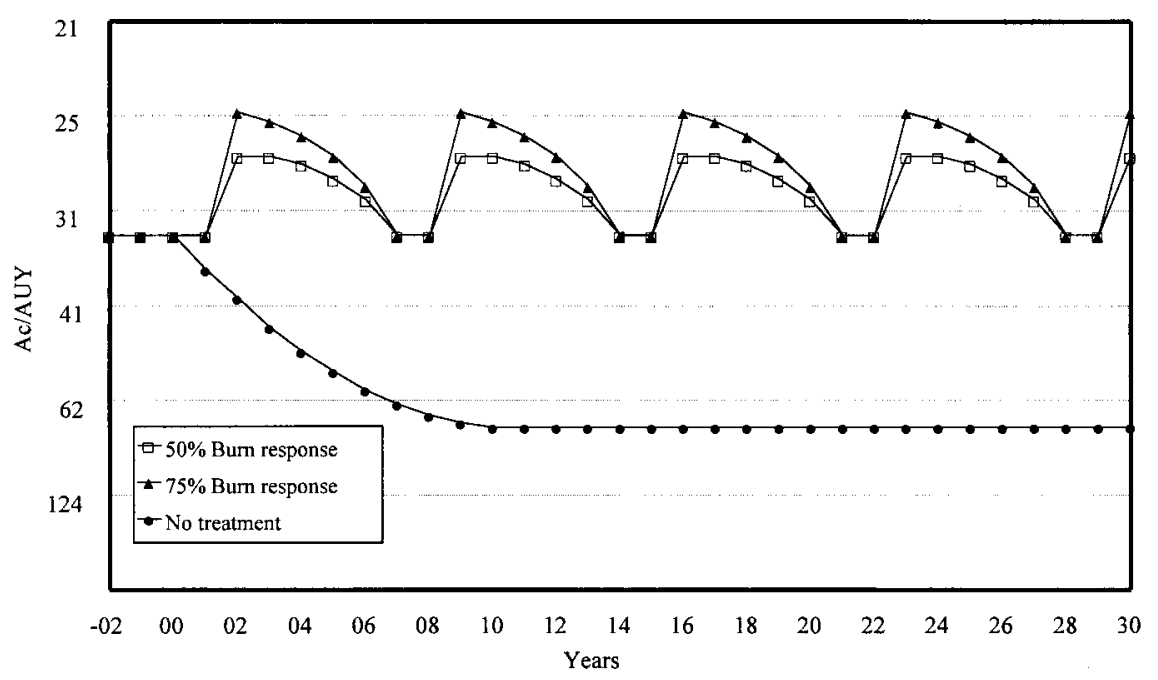

Fig. 2. Carrying capacity of treated compared to untreated mesquite using prescribed burning assuming initial mesquite cover of $20 \%$. Grass growth the season after fire was assumed to be at pretreatment levels. Two possible peak responses in production after treatment are considered, $50 \%$ or $75 \%$ that of herbicide treatment. mesquite aerial cover of $20-30 \%$ is considered desirable, but too much brush is undesirable. Both herbicides and burning can have either positive or negative effects on wildlife depending on how these are applied and managed. The consequences of increasing or decreasing income from wildlife are considered, using a wildlife income of $\$ 3 /$ ac for the whole management unit. Wildlife income is increased to an upper level $(\$ 5 / \mathrm{ac})$ or decreased to a lower level ( $\$ 1 / \mathrm{ac})$ common in north Texas for treated portions of the management unit to simulate positive or negative effects of treating brush on wildlife income.

\section{Putting Dollars To The Scenarios}

In almost all scenarios, both herbicide and prescribed burning treatments were economically feasible since net present values were greater than 0 and benefit-cost ratios were greater than 1. However, both these economic indicators were much greater for prescribed fire than for the herbicide treatment (Table 2), even if the burn treatment was assumed to be only $50 \%$ as effective as the herbicide treatment in reducing brush.

The lowest net present values were for the herbicide treatment with herbi- cide re-treatment after 20 years. When the herbicide treatment with a followup burn after 20 years was compared to the $50 \%$ effective burn, benefit-cost ratio was more than double for the 50 $\%$ effective burn treatment. When the longevity of the herbicide was assumed to be 30 years, net present value increased relative to the 20 -year longevity herbicide treatment, but was still much lower than for the burn treatment.

Net present values of burn scenarios which considered reduced stock numbers (by 10\%) and lower carrying capacity response following fire were greater than those of all the herbicide treatments (Table 2).

The main reason for the low net present values when using herbicide is the high initial treatment cost. Lower net present values were associated with early, large capital expenditures compared to expenditure over the length of the period under examination. The high net present values for prescribed burning were a result of 5 small investments (total cost $\$ 12.50 / \mathrm{ac})$ spread over the 30-year period compared to the large single investment $(\$ 23 / \mathrm{ac}$ ) in year 1 for herbicide application. The cost of the herbicide would need to be less than $\$ 12$ $/ a c$ before net present values for the herbicide treatment would be competitive with $\$ 2.50 / \mathrm{ac}$ or even $\$ 5 / \mathrm{ac}$ for prescribed burns.

However, even at an herbicide cost of $\$ 12$ /ac, the benefit-cost ratios for burns were still greater if the burning cost measured in field experiments $(\$ 2.50)$ is doubled to $\$ 5 / a c$. This analysis showed more sensitivity to cost of herbicide

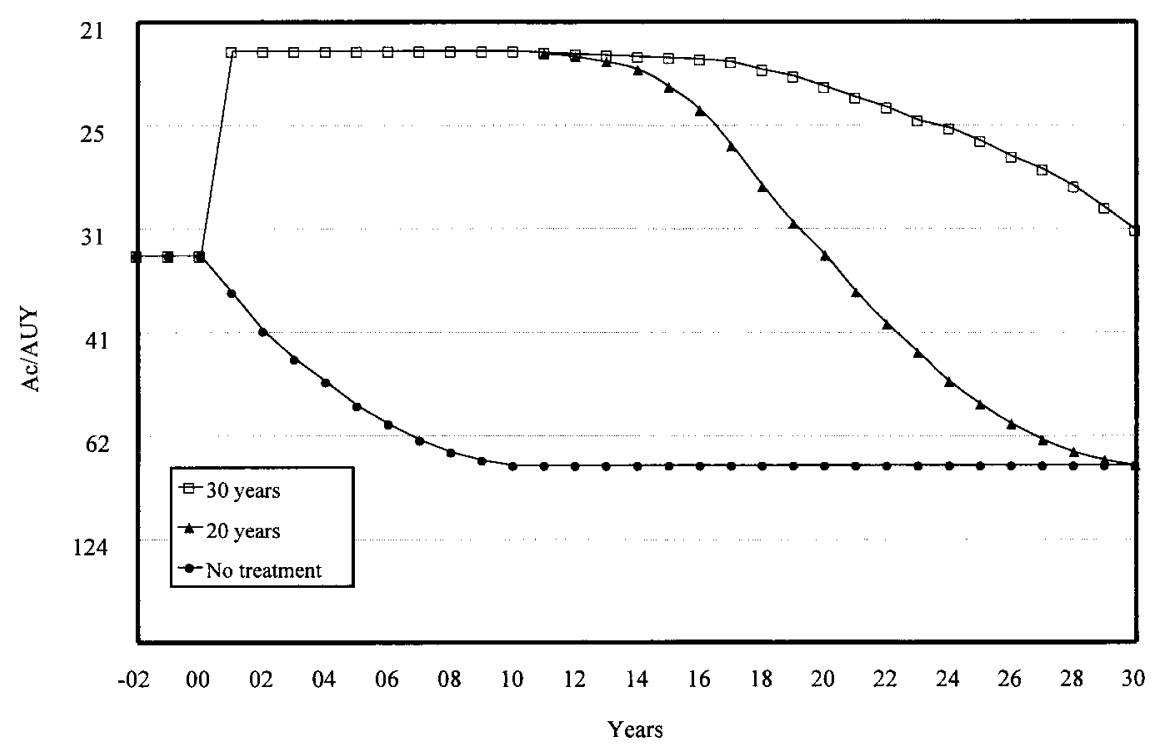

Fig. 3. Carrying capacity of treated compared to untreated mesquite using a root-killing herbicide with treatments lasting 20-and 30-years before pretreatment forage production levels are reached. Assuming initial mesquite cover of $20 \%$. 
Table 2. Consequence of treating mesquite with root-killing herbicides or prescribed fire on Net Present Value and Benefit/Cost ratio under different management and response scenarios.

\begin{tabular}{|c|c|c|c|c|c|c|}
\hline \multirow[t]{2}{*}{ Treatment } & \multirow{2}{*}{$\begin{array}{l}\text { Treatment } \\
\text { Longevity }\end{array}$} & \multirow{2}{*}{$\begin{array}{l}\text { Scenario / Response } \\
\text { Description }\end{array}$} & \multicolumn{2}{|c|}{ Treatment Cost } & \multirow{2}{*}{$\begin{array}{c}\text { Net Present Value } \\
\text { Ratio }\end{array}$} & \multirow[t]{2}{*}{ Benefit-Cost } \\
\hline & & & Initial & Follow-up & & \\
\hline & & & $\cdots \cdots$ & $\cdots$ & & \\
\hline \multirow[t]{5}{*}{ Herbicide } & 20 years & No follow-up & 23 & 0 & 12.2 & 2.3 \\
\hline & 30 years & No follow-up & 23 & 0 & 14.8 & 2.5 \\
\hline & 20 years & Follow-up burns after 20 years & 23 & 2.5 & 13.2 & 2.3 \\
\hline & 20 years & Follow-up burns after 16 years & 23 & 2.5 & 13.6 & 2.3 \\
\hline & 20 years & Herbicide after 20 years & 23 & 23 & 11.0 & 1.8 \\
\hline \multirow[t]{5}{*}{ Burn } & 7 years & Response $50 \%$ of herbicide & 2.5 & 2.5 & 17.3 & 6.8 \\
\hline & 7 years & Response $75 \%$ of herbicide & 2.5 & 2.5 & 18.1 & 16.9 \\
\hline & 7 years & Response not delayed 1 year & 2.5 & 2.5 & 18.5 & 7.0 \\
\hline & 7 years & $10 \%$ fewer animals & 2.5 & 2.5 & 16.2 & 6.8 \\
\hline & 7 years & Continuous graze* & 4.3 & 4.3 & 14.7 & 4.2 \\
\hline
\end{tabular}

than to treatment longevity following herbicide treatment.

It is important to indicate that the results involving prescribed burning in this study refer only to those circumstances where fine fuel amount is at least $1500 \mathrm{lb} / \mathrm{ac}$. In circumstances where the fuel is less than this, the use of prescribed fire to topkill mesquite is not possible. Where the use of prescribed fire is not possible, other means such as herbicide application or mechanical brush removal are usually necessary to restore forage productivity be-

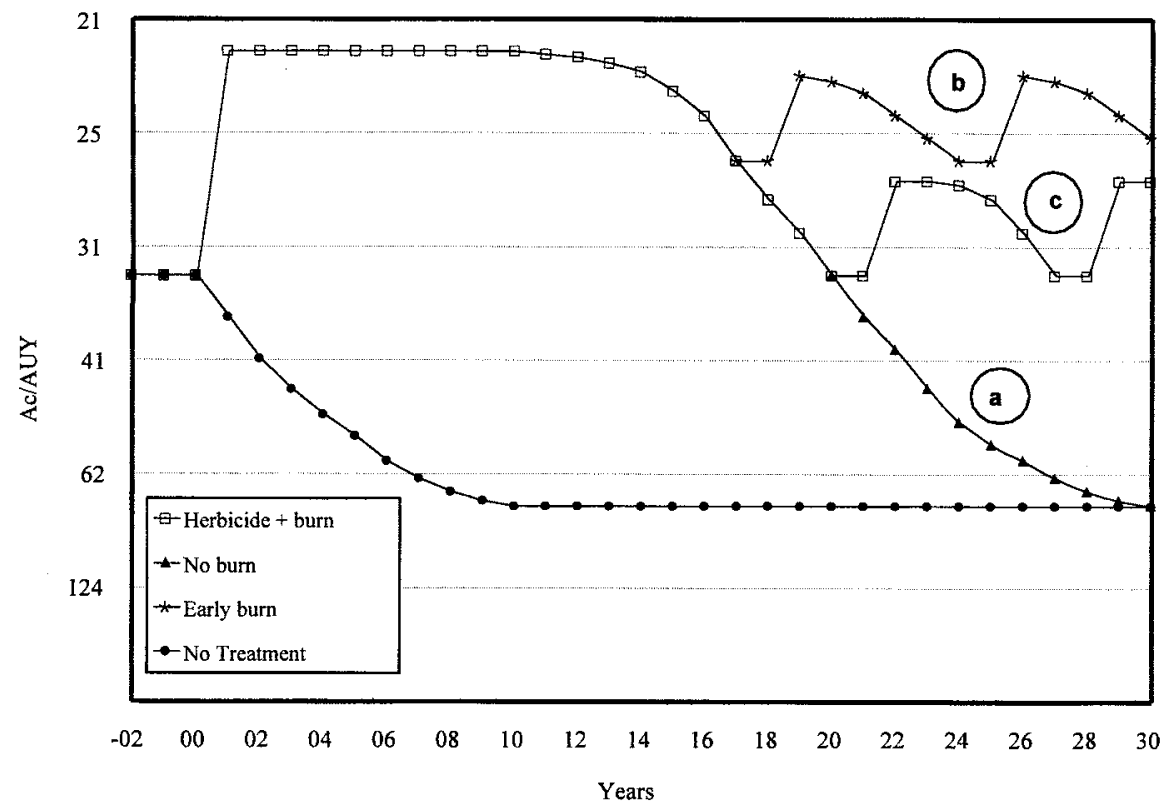

Fig. 4. Carrying capacity of treated compared to untreated mesquite using a root-killing herbicide followed by different post-herbicide treatment prescribed burn scenarios: (a) no burning (b) burning after 16 years and (c) burning after 20 years. Assuming initial mesquite cover of $20 \%$.

fore fire is a viable management option.

The cost of adding fences to facilitate pre- and post-burn deferment decreased net present value very slightly if low-cost electric fencing was used, whereas using 5-wire fencing reduced economic benefits considerably. In both cases, economic returns were considerably less when herbicides were used rather than fire. The most likely and economically rational scenario, burning in a 4-pasture or 8-pasture system without incurring any fencing costs, has considerably greater 

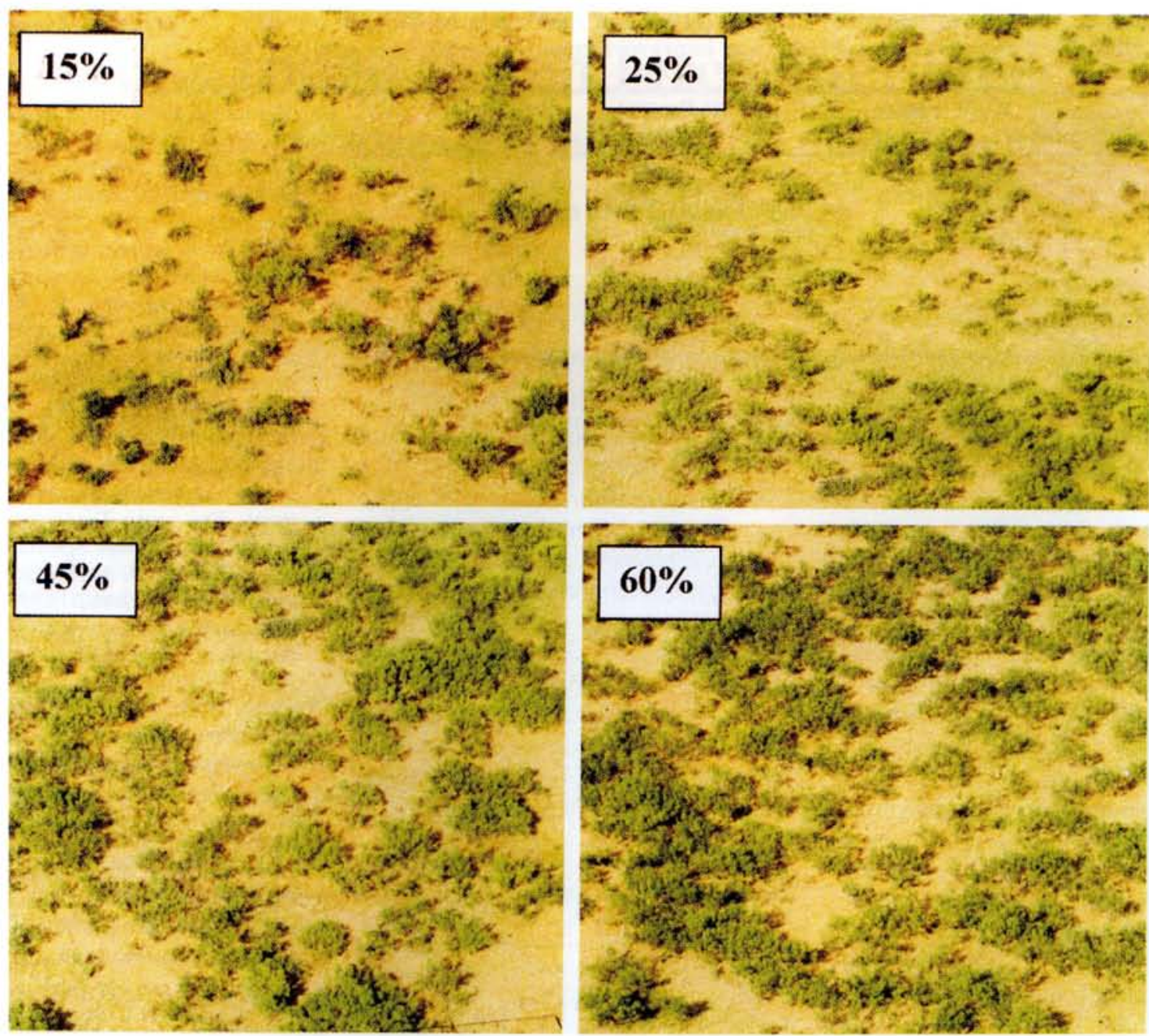

Plate 2. Overhead views of mesquite brush at different aerial cover values.

brush cover, and the herbage production response is delayed 1 year after burning. Even the lowest likely increase in carrying capacity after prescribed burning compares favorably with the herbicide alternatives described above. These analyses indicate that the cost of herbicide treatment would have to be less than half the current cost before it would be economically competitive with fire as a means of controlling mesquite.

Even if fences have to be constructed, the net present values of the herbicide treatment options were lower than those for realistic burning scenarios, but most ranches would be able to implement at least a 4-pasture-1-herd system without any increase in fencing. In addition, grazing systems also have the potential of improving range condition and productivity. Improving range condition applies to both herbicide and fire treatments and would further improve long-term economic benefits.

Wildlife income is extremely important for ranch cash flow and profitability, and the highest economic return from either burning or herbicide treat-

ments would occur if wildlife income were increased as a result of treatment. However, there is a risk that removing too much brush may reduce potential income from wildlife.

Fire is not as easy or convenient to use as chemical treatments for controlling mesquite, but it does offer the opportunity of lowering costs substantial-

Table 3. Projected 30-year economic income over costs after tax following treatment of mesquite with root-killing herbicides or prescribed fire for hypothetical 20,000 -acre ranch.

\begin{tabular}{llllc}
\hline \hline Treatment & $\begin{array}{l}\text { Treatment } \\
\text { Longevity }\end{array}$ & $\begin{array}{c}\text { Scenario/Response } \\
\text { Description }\end{array}$ & \multicolumn{2}{c}{ Income over costs } \\
\cline { 3 - 5 } & & & $\begin{array}{c}\text { Wildlife income } \\
\text { @ \$3/ac }\end{array}$ & $\begin{array}{c}\text { No wildlife } \\
\text { income }\end{array}$ \\
\hline Herbicide & 20 years & No follow-up burn & 2.27 & 0.74 \\
Burn & 7 years & Response delayed 1 year & 3.19 & 1.39 \\
\hline
\end{tabular}


Table 4. Effect on Net Present Value and Benefit/Cost ratio of root-killing herbicides and prescribed fire if mesquite removal reduces or improves income from wildlife.

\begin{tabular}{|c|c|c|c|c|}
\hline \multirow[t]{2}{*}{ Treatment } & \multicolumn{2}{|c|}{$\begin{array}{l}\text { Wildlife lease } \\
\end{array}$} & \multirow{2}{*}{$\begin{array}{c}\text { Net Present } \\
\text { Value }\end{array}$} & \multirow{2}{*}{$\begin{array}{c}\text { Benefit-Cost } \\
\text { Ratio }\end{array}$} \\
\hline & Untreated area & Treated area & & \\
\hline & $\ldots \ldots-(\$ / a c$ & $\ldots \ldots \ldots$ & $(\$ / a c)$ & \\
\hline \multirow[t]{3}{*}{ Herbicide } & 3 & 3 & 13.2 & 2.3 \\
\hline & 3 & 1 & {$[-12.9]$} & {$[-0.2]$} \\
\hline & 3 & 5 & 39.4 & 4.8 \\
\hline \multirow[t]{3}{*}{ Burn } & 3 & 3 & 17.3 & 6.8 \\
\hline & 3 & 1 & {$[-8.2]$} & {$[-1.7]$} \\
\hline & 3 & 5 & 44.11 & 5.3 \\
\hline
\end{tabular}

ly by substituting management for capital inputs to increase profit margins.

In times of below-average rainfall, burning can be very difficult or impossible to implement. Reducing stock numbers and burning only $1 / 8$ of a grazing management unit each year would help considerably in ensuring that regular burns are possible in all but abnormally dry years. Fire also will not kill mesquite, whereas the newer herbicide products will. However, under adequate management it should be possible to burn frequently enough to keep mesquite in a suppressed condition.

These analyses show that prescribed burning would be very economically competitive with large-scale herbicide treatment on large ranches. This analysis indicates that there is an economic advantage to using fire wherever possible and restricting use of her- bicides to those situations in which fire is not a viable option.

There is a greater certainty of applying effective burn treatments when mesquite cover is less than $20 \%$ because greater amounts of brush cover reduce the amount of grass and lower the amount of fuel to carry fire and achieve adequate brush control. This would be accentuated during drought years. Once mesquite cover exceeds $20 \%$, the use of the more expensive herbicide treatment may be unavoidable.

Authors Teague, Ansley and Pinchak are with Texas Agricultural Experiment Station, Kreuter is with Department of Rangeland Ecology and Management, Texas A\&M University, College Station, Texas 77843. Author McGrann is with Department of Agricultural Economics, Texas A\&M University, College Station, Texas 77843.

${ }^{\prime}$ Author to contact. See Website at http://www.juniper.tamu.edu P.O. Box 1658, Vernon, Texas 76385. Author

\section{References}

Ansley, R.J. and P.W. Jacoby. 1998. Manipulation of fire intensity to achieve mesquite management goals in north Texas, p.195-204. In: Teresa L. Pruden and Leonard A. Brennan (eds.). Fire in ecosystem management: shifting the paradigm from suppression to prescription. Tall Timbers Fire Ecology Conference Proceedings, No. 20. Tall Timbers Research Station, Tallahassee, Florida.

Norton, B.E. 1998. The application of grazing management to increase sustainable livestock production. Animal Production in Australia 22:15-26.

Scifres, C.J. and W.T. Hamilton. 1993. Prescribed burning for brushland management: The south Texas example. Texas A\&M Press, College Station, Texas.

Teague, W.R., R.J. Ansley, J.M. McGrann and W.E. Pinchak. 1999. Developing sustainable management strategies for mesquite rangeland. Rev. Argentina. Prod. Anim. 19:37-46.

Teague, W.R., R.J. Ansley, U.P. Kreuter, W.E. Pinchak and J.M. McGrann. 2001. Economics of managing mesquite in north Texas: a sensitivity analysis. J. Range Manage. 54:553-560.

Ueckert, D.N., W.A. McGinty, and U.P. Kreuter. 1999. Brush busters: marketing Prosopis management technology, p.580581. Proc. VI ${ }^{\text {th }}$ Int. Rangeland Congr. Soc. Range Manage., Townsville, Queensland. 